\title{
Evaluation of Native Bacterial Consortium from Crude Oil-Impacted Tropical Environment for Integration into Bioremediation Process
}

\author{
Olusola A. Ojo-Omoniyi ${ }^{1,2 *}$ and Rebecca O. Abegunrin ${ }^{1}$ \\ ${ }^{1}$ Department of Microbiology, Faculty of Science, Lagos State University, Lagos-Nigeria \\ P. M. B. 0001 LASU Post office, Lagos-Nigeria \\ ${ }^{2}$ Department of Biological Sciences, Covenant University, Ota, Nigeria \\ *Corresponding author
}

\section{Keywords}

Antibiotic-

resistance, Bacterial

consortium,

Biodegradation,

Bioremediation,

Petroleum

hydrocarbon,

Plasmid DNA

Article Info

Accepted:

12 May 2019

Available Online:

10 June 2019

\section{A B S T R A C T}

Petroleum-based products are the major source of energy for industry and daily life. Leaks and accidental spills occur regularly during the exploration, production, refining, transport, and storage of petroleum and petroleum products. Crude oil-impacted tropical soil and natural water samples $(0-30 \mathrm{~cm}$ depth) were obtained from the Niger Delta, Nigeria. A total of twenty seven bacterial species of relevance in bioremediation were isolated and characterized using standard and conventional methods. The predominant species belong to the genera Pseudomonas and Proteus. The ability of Pseudomonas aeruginosa, Pseudomonas stutzeri, Proteus mirabilis, Serratia marcescens and Bacillus subtilis to degrade diesel oil was studied. The results showed maximal increase in optical densities and total viable counts, however, with decrease in $\mathrm{pH}$ of the culture media after 8 - day incubation period. Typical generation times varied between 0.89 and $4.0 \mathrm{~d}$ for Pseudomonas aeruginosa, 0.85 and $0.32 \mathrm{~d}$ for Pseudomonas stutzeri, 0.8 and $3.9 \mathrm{~d}$ for Proteus mirabilis. All the isolates utilized petroleum hydrocarbon as sole carbon and energy sources for growth on Minimal Salt Medium (MSM) supplemented with (0.2\%) diesel oil. The isolates were tested against 7 different antibiotics and were found to be resistant to 5 antibiotics. Consequently, Twenty four isolates were randomly selected for plasmid DNA isolation. The presence of plasmid DNA was confirmed in 22 isolates where the molecular weight size ranged between $7-23.1 \mathrm{~kb}$. Although, Pseudomonas aeruginosa, Proteus mirabilis and Bacillus subtilis had low specific growth rate on Diesel, they were the best choice for bioremediation since they had the highest mean generation time respectively. The knowledge of the potentials of these isolates to degrade hydrocarbons will increase the possibilities of developing novel strains and strategies for removing hydrocarbon pollutants from the natural environment.

\section{Introduction}

Oil and gas companies operating in Nigeria burn over $\$ 3.5$ to $\$ 5$ billion yearly from the over 257 flow stations in the Niger Delta. Specifically the country flared about 17.15 percent of the 95.471 metric tons of gas produced in June, 2015 alone, according to 
data from Nigerian National Petroleum Corporation (NNPC) (Anonymous, 2015). The Nigerian environment is characterized by lack of concern, indiscriminate and highly unregulated disposal of petroleum products including diesel and engine oil (Odjegba and Sadiq, 2000). However, increased demand for petroleum as a consequence of industrialization has greatly increased the background level of exposure of the environment to different hydrocarbons (Odell, 2013). However, these compounds are slowly degraded by a large variety of microorganisms. All the activities in the oil industries, including exploration, extraction, transportation, refining and oily waste management, are possible sources of environmental pollution (Hu et al., 2013). The US EPA has classified these compounds as priority contaminants of natural resources (Husain, 2008).

The effluents of petroleum wells, oil refinery operations, industrial wastewaters, fuel consumption, wood-processing activities, detergents, pesticides, paints and other chemicals release huge quantities of hydrocarbons into soil and air (Rosenberg, 2013). Crude oils contain a mixture of different low- and high-molecular-weight aliphatic hydrocarbons and several types of monocyclic and polycyclic aromatic compounds, in which one or more of the carbon atoms in their backbone can also be substituted by Nitrogen, Sulphur or Oxygen. The length and nature of hydrocarbons varies in oil-derived compounds from $\mathrm{C}_{1}-\mathrm{C}_{10}$, such as make up gasoline (Jimeson et al., 2012); $\mathrm{C}_{9}-\mathrm{C}_{16}$, such as are found in jet fuel and kerosene (Chou et al., 2002); and $\mathrm{C}_{10}-\mathrm{C}_{50}$, such as waste oil (Monserud and Schwartz, 2012). On the other hand, metabolism of hydrocarbons by microorganisms is a relatively complex process in which the microorganisms first take up the hydrocarbons and then convert these metabolically inactive molecules to more active forms for further catalysis (Ladygina $e t$ al., 2006).

To determine the potentials of the bacterial consortium at utilizing petroleum hydrocarbon as source of carbon and energy for growth

To determine if the metabolic capabilities of the consortium were plasmid-mediated

To evaluate the potentials of native bacterial consortium for integration into bioremediation strategy for a tropical crude oil-impacted environment.

\section{Materials and Methods}

\section{Sample collection}

Crude oil - polluted soil and water samples were obtained from Lagos and River States in Nigeria in an earlier study, from which twenty - seven petroleum - hydrocarbon utilizers were isolated. These isolates were subsequently cultured on bacteriological media supplemented with Diesel oil at $0.2 \%$.

\section{Bacteriology}

The isolates were later sub-cultured on different selective media and Nutrient agar in order to develop pure cultures and identify the bacterial cells.

The pure cultures of bacterial cells were thereafter grown on Mueller Hinton Agar for plasmid extraction and antibiotic sensitivity testing at $26 \pm 2^{\circ} \mathrm{C}$ for 24 hours (Bridson and Brecker, 1970; Olukoya and Oni,1990).

\section{Minimal salt medium}

The Minimal Salt Medium (MSM) contained: $12.8 \mathrm{~g} \quad \mathrm{Na}_{2} \mathrm{HPO}_{4} .7 \mathrm{H}_{2} \mathrm{O}, \quad 6 \mathrm{~g} \quad \mathrm{Na}_{2} \mathrm{HPO}_{4}, \quad 3 \mathrm{~g}$ $\mathrm{KH}_{2} \mathrm{PO}_{4}, \quad 0.5 \mathrm{~g} \quad \mathrm{Nacl}, \quad 1 \mathrm{~g} \quad \mathrm{NH}_{4} \mathrm{cl}, 200 \mathrm{ml}$ micronutrients and $0.2 \%$ carbon source. The 
$\mathrm{pH}$ of the medium was adjusted to 7.4 with $\mathrm{NaOH}$ before autoclaving (Mills et al., 1978).

\section{Micromorphological and biochemical characterization of isolated bacteria}

All isolates were examined and characterized using standard and conventional methods. The biochemical tests used for characterization of isolates includes; Gram staining, carbohydrate fermentation tests, catalase test, Kligler-Iron agar(KIA), Indole test, Oxidase test, Motility test, Methyl Red test, Voges Proskauer test (Gerhardt et al., 1981; Holt et al., 1994; Isenberg, 2004).

\section{Growth of bacteria isolates on hydrocarbon substrate}

The Time - course degradation of diesel oil was performed using Minimal salts medium (Mills et al., 1978). The medium was dispensed in $99 \mathrm{ml}$ quantity into $250 \mathrm{ml}$ Erlenmeyer flasks. Each flask was supplemented with $1 \mathrm{ml}$ of diesel as the carbon source.

The flasks were cultivated in a gyratory shaker incubator at $150 \mathrm{rpm}$ and $28^{\circ} \mathrm{C}$ for 8days. The turbidity by optical density measurement (OD600nm) using spectrophotometer (Spectrum lab S23A, Globe Medical, England), total viable count (TVC) and $\mathrm{pH}$ of the culture fluids were monitored at pre - determined time intervals as biodegradation indices (Mills et al., 1978).

\section{Antibiotic susceptibility test}

Sensitivity and resistance of isolate to antimicrobial agents was determined on Mueller Hinton agar, using the disc diffusion technique (Kasper et al., 1990). Bacteria strains resistant to the antibiotics grew up to the edges of the disc while the growth of those susceptible to the antibiotics was inhibited.

\section{Isolation of plasmid}

The bacteria isolate was inoculated into $2 \mathrm{ml}$ of trypticase soy broth and grown overnight at $37^{\circ} \mathrm{C}$ in the shaker. $1.5 \mathrm{ml}$ of the overnight culture was transferred to $1.5 \mathrm{ml}$ micro centrifuge tube. It was centrifuged at 10,000rpm for 5 minutes. The supernatant was discarded and the liquid drained by inverting on the blotting paper. The tube was kept on ice. The cell pellet was re-suspended in $100 \mu \mathrm{l}$ of ice cold solution I $(50 \mathrm{mM}$ Glucose, 25mM Tris; $\mathrm{pH}$ 8.0, 10mM EDTA) and mixed by vortexing gently. It was kept at room temperature for 5 minutes. $200 \mu 1$ of solution II $(0.2 \mathrm{M} \mathrm{NaOH}, 1 \% \mathrm{SDS})$ was added and gently mixed by inverting the tube 5 times. $150 \mu 1$ of solution III (3M potassium acetate, $\mathrm{pH}$ 5.5) was added and gently mixed, the tube was placed on ice for 5 minutes. It was centrifuged at $10,000 \mathrm{rpm}$ for 10 minutes. The supernatant was transferred into a fresh tube and $450 \mu$ l of isopropanol was added, the content was mixed by inverting the tube. It was centrifuged at $10,000 \mathrm{rpm}$ for 10minutes. The supernatant was removed carefully and discarded. The DNA was seen as white precipitate sticking to the wall of the tube. $1 \mathrm{ml}$ of $70 \%$ ethanol was added to wash the pellet, the contents was mixed by inverting and centrifuged at $10,000 \mathrm{rpm}$ for 10 minutes. The supernatant was removed completely and the pellet dried by keeping the cap of the tube open. $30 \mu \mathrm{l}$ of autoclaved distilled water was added and gently mixed by tapping the sides of the tube to dissolve the DNA. It was allowed to stand at room temperature with intermittent mixing for 15 20 minutes. The DNA was checked by $0.8 \%$ agarose gel electrophoresis by loading $5 \mu 1$ of DNA sample (Kado and Liu, 1981; Sambrook et al., 1989; Olukoya and Oni, 1990).

\section{Results and Discussion}

Pseudomonas species have been reported by several authors to have capability for 
mineralizing petroleum hydrocarbons especially in environment receiving petroleum waste discharges (Scoboszlay et al., 2003; Okoh and Trejo-Hernandez, 2006; Das and Mukherjee, 2007). This corroborated our findings from the degradation - Time course study. Typical doubling times on diesel ranged from 0.89 - $4.0 \mathrm{~d}$ for Pseudomonas aeruginosa, $0.85-0.32 \mathrm{~d}$ for
Pseudomonas stutzeri; 0.8 - 3.9d for Proteus mirabilis (Table 4). Pseudomonas aeruginosa, Proteus mirabilis and Bacillus subtilis were the best choice for bioremediation because they had low specific growth rate which suggested that the organisms were making use of the diesel oil as their source of carbon and energy (Fig. 1-7 and Table 1-8).

Table.1 Bacterial isolates screened for petroleum- hydrocarbon utilization

\begin{tabular}{|c|c|}
\hline Bacteria & Frequency $(\%)$ \\
\hline Pseudomonas aeruginosa & $\mathbf{8}(\mathbf{2 9 . 6})$ \\
Pseudomonas stutzeri & $6(22.3)$ \\
Proteus mirabilis & $\mathbf{8}(\mathbf{2 9 . 6})$ \\
Serratia marcescens & $2(7.4)$ \\
Escherichia coli & $1(3.7)$ \\
Bacillus subtilis & $2(7.4)$ \\
Total & $27(\mathbf{1 0 0})$ \\
\hline
\end{tabular}

Table.2 Biochemical characteristics of the bacterial isolates screened for petroleumhydrocarbon utilization

\begin{tabular}{|c|c|}
\hline Biochemical characteristics & $\mathbf{N}(\%)$ \\
\hline Gram reaction & \\
+ & $2(7.4)$ \\
- & $25(92.6)$ \\
Lactose fermentation & $3(11.1)$ \\
Glucose fermentation & $2(7.4)$ \\
Sucrose fermentation & $27(100)$ \\
Arabinose fermentation & $24(81.5)$ \\
Urease production & $22(81.5)$ \\
Oxidase production & $14(51.9)$ \\
Pyocyanin production $_{\text {Growth at 42 }}^{\circ}$ C & $14(51.9)$ \\
Growth in 10\% NaCl & $16(59.3)$ \\
Indole production & $12(44.4)$ \\
Arginine utilization & $3(11.1)$ \\
Lysine utilisation & $16(59.3)$ \\
Catalase production & $10(37)$ \\
Hydrogensulphide production & $25(92.6)$ \\
Gas from sucrose fermentation & $\mathbf{8}(29.6)$ \\
Voges-Proskauer & $25(92.6)$ \\
Methyl red & $2(7.4)$ \\
\hline
\end{tabular}


Table.3 The growth potential of hydrocarbon utilizing bacteria screened

\begin{tabular}{|c|c|c|}
\hline \multirow[t]{3}{*}{ Isolates } & \multirow{2}{*}{\multicolumn{2}{|c|}{$\begin{array}{c}\text { Hydrocarbon source } \\
\text { Diesel }\end{array}$}} \\
\hline & & \\
\hline & $m\left(d^{-1}\right)^{a}$ & $\mathbf{T}(\mathbf{d})^{\mathbf{b}}$ \\
\hline Pseudomonas aeruginosa01 & 0.72 & 2.4 \\
\hline Pseudomonas aeruginosa02 & 0.75 & 2.2 \\
\hline Pseudomonas aeruginosa03 & 1.05 & 0.89 \\
\hline Pseudomonas aeruginosa04 & 0.66 & 3.4 \\
\hline Pseudomonas aeruginosa05 & 0.62 & 3.8 \\
\hline Pseudomonas aeruginosa06 & 0.82 & 2 \\
\hline Pseudomonas aeruginosa07 & 0.75 & 2.2 \\
\hline Pseudomonas aeruginosa08 & 0.63 & 4 \\
\hline Pseudomonas stutzeri01 & 0.91 & 1.5 \\
\hline Pseudomonas stutzeri02 & 0.68 & 3.2 \\
\hline Pseudomonas stutzeri03 & 0.74 & 2.3 \\
\hline Pseudomonas stutzeri04 & 1.06 & 0.88 \\
\hline Pseudomonas stutzeri05 & 1.05 & 0.89 \\
\hline Pseudomonas stutzeri06 & 1.08 & 0.85 \\
\hline Proteus mirabilis 01 & 1.10 & 0.8 \\
\hline Proteus mirabilis 02 & 0.69 & 3 \\
\hline Proteus mirabilis 03 & 0.73 & 2.1 \\
\hline Proteus mirabilis 04 & 0.74 & 2.1 \\
\hline Proteus mirabilis 05 & 0.85 & 1.8 \\
\hline Proteus mirabilis 06 & 0.69 & 3.2 \\
\hline Proteus mirabilis 07 & 0.82 & 1.9 \\
\hline Proteus mirabilis 08 & 0.64 & 3.9 \\
\hline Serratia marcescens01 & 0.69 & 3.2 \\
\hline Serratia marcescens02 & 0.72 & 2.4 \\
\hline Escherichia coli 01 & 0.71 & 2.3 \\
\hline Bacillus subtilis 01 & 0.59 & 4.2 \\
\hline Bacillus subtilis 02 & 0.52 & 4.4 \\
\hline
\end{tabular}

$\mathrm{a}$ - specific growth rate, $\mathrm{b}$ - mean generation time 
Table.4 Antibiogram profile of bacterial isolates

\begin{tabular}{|c|c|c|c|c|c|c|c|c|}
\hline & AMP & CAZ & OFL & AUG & NIT & GEN & CRX & MAR index \\
\hline Pseudomonas aeruginosa 01 & $\mathrm{R}$ & $\mathrm{R}$ & $\mathrm{S}$ & $\mathrm{S}$ & $\mathrm{S}$ & $\mathrm{S}$ & $\mathrm{R}$ & 0.42 \\
\hline Pseudomonas aeruginosa 02 & $\mathrm{R}$ & $\mathrm{R}$ & S & S & S & S & S & 0.29 \\
\hline Pseudomonas aeruginosa 03 & $\mathrm{R}$ & S & $\mathrm{R}$ & $S$ & $\mathrm{R}$ & S & $S$ & 0.42 \\
\hline Pseudomonas aeruginosa 04 & $\mathrm{R}$ & $\mathrm{R}$ & S & S & S & S & S & 0.29 \\
\hline Pseudomonas aeruginosa 05 & $\mathrm{R}$ & $\mathrm{S}$ & S & S & $\mathrm{R}$ & $\mathrm{S}$ & $\mathrm{S}$ & 0.29 \\
\hline Pseudomonas aeruginosa 06 & $\mathrm{R}$ & S & S & S & S & S & S & 0.14 \\
\hline Pseudomonas aeruginosa 07 & $\mathrm{R}$ & S & S & S & $\mathrm{R}$ & S & $\mathrm{R}$ & 0.42 \\
\hline Pseudomonas aeruginosa 08 & $\mathrm{R}$ & S & S & S & S & S & S & 0.14 \\
\hline Pseudomonas stutzeri 01 & $\mathrm{R}$ & S & S & S & S & S & $S$ & 0.14 \\
\hline Pseudomonas stutzeri 02 & S & S & S & S & S & S & $S$ & 0 \\
\hline Pseudomonas stutzeri 03 & S & S & S & $S$ & S & S & $S$ & 0 \\
\hline Pseudomonas stutzeri 04 & $\mathrm{R}$ & $\mathrm{R}$ & S & S & $\mathrm{S}$ & S & S & 0.29 \\
\hline Pseudomonas stutzeri 05 & $\mathrm{R}$ & S & S & S & S & $\mathrm{S}$ & $S$ & 0.14 \\
\hline Pseudomonas stutzeri 06 & $\mathrm{R}$ & S & S & S & $\mathrm{S}$ & S & S & 0.14 \\
\hline Proteus mirabilis 01 & $\mathrm{R}$ & S & S & S & S & S & $\mathrm{S}$ & 0.14 \\
\hline Proteus mirabilis 02 & S & S & S & S & S & S & $\mathrm{S}$ & 0 \\
\hline Proteus mirabilis 03 & $\mathrm{R}$ & S & S & S & S & S & S & 0.14 \\
\hline Proteus mirabilis 04 & $\mathrm{R}$ & S & S & S & S & S & S & 0.14 \\
\hline Proteus mirabilis 05 & $\mathrm{R}$ & S & S & S & $\mathrm{R}$ & S & S & 0.29 \\
\hline Proteus mirabilis 06 & $\mathrm{R}$ & S & S & S & $\mathrm{S}$ & S & S & 0.14 \\
\hline Proteus mirabilis 07 & $\mathrm{R}$ & S & S & S & S & S & S & 0.14 \\
\hline Proteus mirabilis 08 & S & S & S & S & S & $\mathrm{S}$ & $\mathrm{S}$ & 0 \\
\hline Serratia marcescens01 & $\mathrm{R}$ & $\mathrm{R}$ & S & S & $\mathrm{S}$ & S & $\mathrm{R}$ & 0.42 \\
\hline Serratia marcescens 02 & S & S & S & S & S & S & S & 0 \\
\hline Escherichia coli & $\mathrm{R}$ & S & S & S & S & S & S & 0.14 \\
\hline Bacillus subtilis 01 & S & S & S & S & S & S & S & 0 \\
\hline Bacillus subtilis 02 & S & S & S & S & S & S & S & 0 \\
\hline
\end{tabular}

Key:

$\mathrm{R}-$ Resistance

$\mathrm{S}-$ Sensitive

MAR index - ratio of number of antibiotic resisted to number of antibiotics tested.

AMP - Ampicillin

CAZ - Cefrihzidime

OFL - Ofloxacin

AUG - Clavulanate

NIT - Nitrofurantoin

GEN - Gentamicin

CRX - Ceftriroxime 
Table.5 Antibiotic resistance of the bacterial isolates

\begin{tabular}{|c|c|c|c|c|c|c|c|}
\hline \multirow[t]{2}{*}{ Antibiotics } & P. aeruginosa & P. stutzeri & Proteus mirabilis & Serratia marcescens & E. coli & Bacillus subtilis & Total \\
\hline & $(N-8)$ & $(N-6)$ & $(N-8)$ & $(N-2)$ & $(N-1)$ & $(N-2)$ & $(\%)$ \\
\hline AMP & $8((100 \%)$ & $4(66.6 \%)$ & $6(75 \%)$ & $1(50 \%)$ & $1(50 \%)$ & 0 & $20(74.07 \%)$ \\
\hline CAZ & $3(37.5 \%)$ & $1(16.66 \%)$ & 0 & $1(50 \%)$ & 0 & 0 & $5(18.51 \%)$ \\
\hline OFL & $1(12.5 \%)$ & 0 & 0 & 0 & 0 & 0 & $1(3.70 \%)$ \\
\hline AUG & 0 & 0 & 0 & 0 & 0 & 0 & 0 \\
\hline NIT & $3(38 \%)$ & 0 & $1(12.5 \%)$ & 0 & 0 & 0 & $4(14.81 \%)$ \\
\hline GEN & 0 & 0 & 0 & 0 & 0 & 0 & 0 \\
\hline CRX & $2(25 \%)$ & 0 & 0 & $1(50 \%)$ & 0 & 0 & $3(11.11 \%)$ \\
\hline
\end{tabular}

KEY:
AMP - Ampicillin

CAZ - Cefrihzidime

OFL - Ofloxacin

AUG - Clavulanate

NIT - Nitrofuranto

GEN - Gentamtoin

CRX - ceftriroxime

Table.6 Antibiotic resistance pattern of the bacterial isolates to various antibiotics

\begin{tabular}{|c|c|c|c|c|c|c|c|c|}
\hline $\begin{array}{c}\text { Drug resistant } \\
\text { pattern }\end{array}$ & $\begin{array}{l}\text { Number of } \\
\text { antibiotics }\end{array}$ & $\begin{array}{c}\text { Pseudomonas } \\
\text { aeruginosa }\end{array}$ & $\begin{array}{c}\text { Pseudomonas } \\
\text { stutzeri }\end{array}$ & $\begin{array}{l}\text { Proteus } \\
\text { mirabilis }\end{array}$ & $\begin{array}{c}\text { Serratia } \\
\text { marcescens }\end{array}$ & $\begin{array}{c}\text { Escherichia } \\
\text { coli }\end{array}$ & $\begin{array}{l}\text { Bacillus } \\
\text { subtilis }\end{array}$ & $\begin{array}{c}\text { Total } \\
(\%)\end{array}$ \\
\hline AMP, CAZ, CRX & 3 & 1 & 0 & 0 & 1 & 0 & 0 & $2(28.6 \%)$ \\
\hline AMP, CAZ & 2 & 2 & 1 & 0 & 0 & 0 & 0 & $3(42.9 \%)$ \\
\hline AMP, OFL, NIT & 3 & 1 & 0 & 0 & 0 & 0 & 0 & $1(14.3 \%)$ \\
\hline AMP, NIT & 2 & 1 & 0 & 1 & 0 & 0 & 0 & $2(28.9 \%)$ \\
\hline AMP & 1 & 2 & 3 & 5 & 0 & 1 & 0 & $\begin{array}{c}11 \\
(157.1 \%)\end{array}$ \\
\hline AMP, NIT, CRX & 3 & 1 & 0 & 0 & 0 & 0 & 0 & $1(14.3 \%)$ \\
\hline
\end{tabular}

KEY:

AMP - Ampicillin

CAZ - Cefrihzidime

OFL - Ofloxacin

AUG - Clavulanate

NIT - Nitrofurantoin

GEN - Gentamicin

CRX - ceftriroxime 
Table.7 Plasmid profile result of the isolate

\begin{tabular}{|c|c|c|c|}
\hline Lane & Isolate & No. of plasmids & Size, $\mathbf{k b}$ \\
\hline Lane 1 & 1 kb DNA marker & $\mathbf{1 0}$ & $\mathbf{1 0}-\mathbf{1} \mathbf{~ k b}$ \\
Lane 2 & Proteus mirabilis 01 & 2 & $23.1,15$ \\
Lane 3 & Proteus mirabilis 02 & 1 & 15 \\
Lane 4 & Proteus mirabilis 03 & 3 & $23.1,15,7$ \\
Lane 5 & Proteus mirabilis 04 & 1 & 15 \\
Lane 6 & Proteus mirabilis 05 & 0 & 0 \\
Lane 7 & Proteus mirabilis 06 & 3 & $23.1,17,7$ \\
Lane 8 & Proteus mirabilis 07 & 3 & $23.1,15,7$ \\
Lane 9 & Proteus mirabilis 08 & 3 & $23.1,15,7$ \\
Lane 10 & Serratia marcescens 01 & 0 & 0 \\
Lane 11 & Serratia marcescens02 & 1 & 15 \\
Lane 12 & Escherichia coli & 1 & 15 \\
Lane 13 & Escherichia coli & 1 & 15 \\
& & & \\
\hline
\end{tabular}

Table.8 Plasmid profile result of the isolates

\begin{tabular}{|c|c|c|c|}
\hline Isolate & Lane & No. of plasmids & Size, $\mathbf{k b}$ \\
\hline Pseudomonas aeruginosa 01 & 2 & 2 & 10,9 \\
Pseudomonas aeruginosa 02 & 3 & 2 & 10,9 \\
Pseudomonas aeruginosa 03 & 4 & 1 & 10 \\
Pseudomonas aeruginosa 04 & 5 & 3 & $10,9,7$ \\
Pseudomonas aeruginosa 05 & 6 & 3 & $10,9,7$ \\
Pseudomonas aeruginosa 06 & 6 & 3 & $10,9,7$ \\
Pseudomonas aeruginosa 07 & 7 & 3 & $10,9,7$ \\
Pseudomonas aeruginosa 08 & 8 & 3 & $10,9,7$ \\
Pseudomonas stutzeri 01 & 9 & 1 & 10 \\
Pseudomonas stutzeri 02 & 10 & 2 & 10,9 \\
Pseudomonas stutzeri 03 & 11 & 1 & 10 \\
Pseudomonas stutzeri 04 & 12 & 3 & $10,9,7$ \\
& & & \\
\hline
\end{tabular}


Int.J.Curr.Microbiol.App.Sci (2019) 8(6): 1291-1302

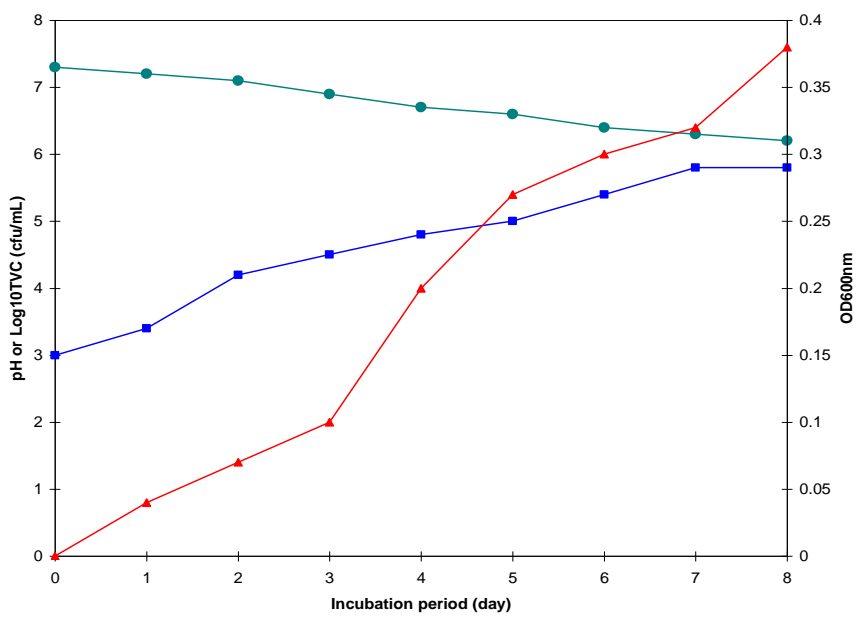

Figure 1. Growth profile of Pseudomonas aeruginosa 02 on diesel

$\rightarrow-\log T V C(\mathrm{cfu} / \mathrm{mL})$

$-\mathrm{pH}$ of culture medium

$\rightarrow$ OD600nm
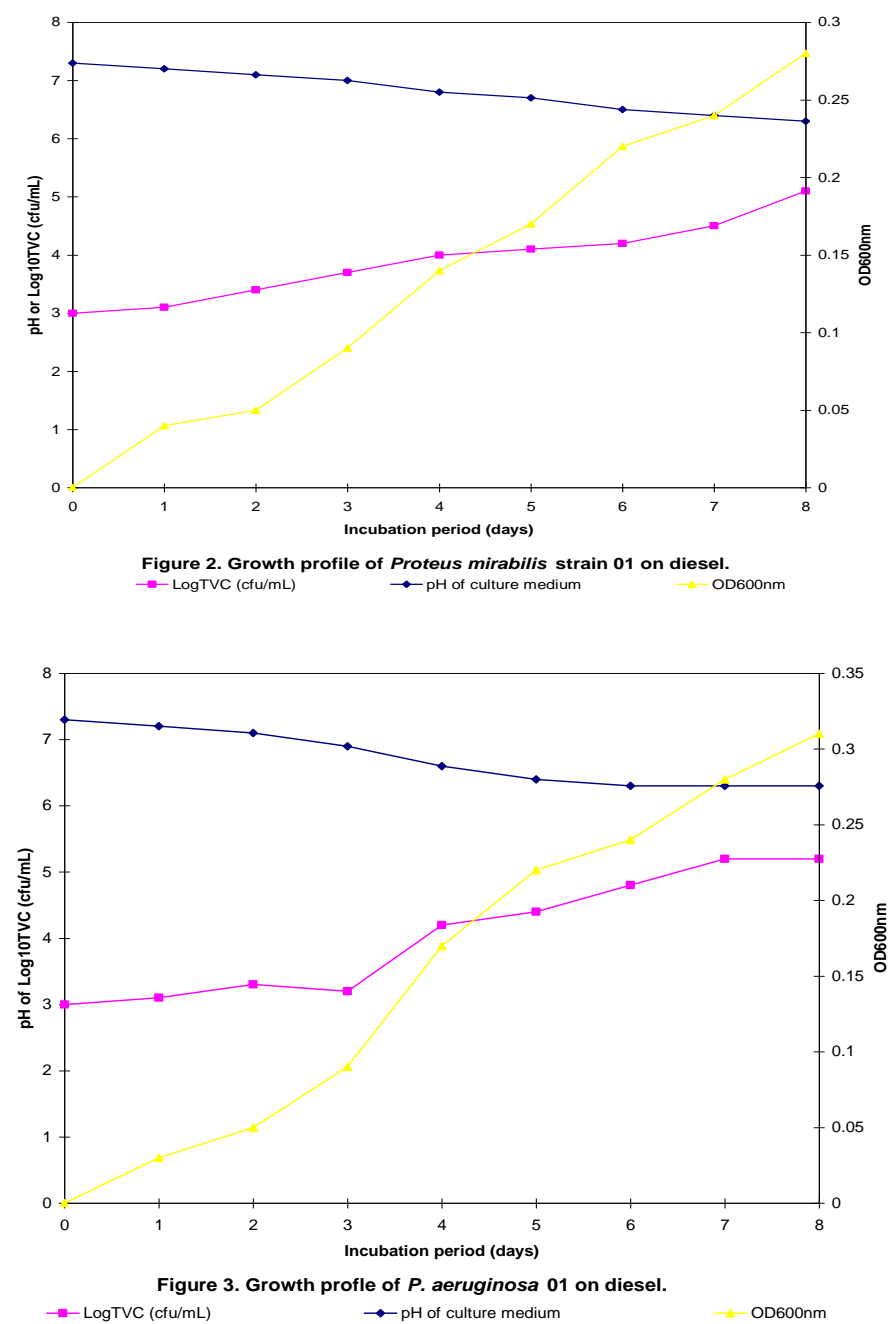


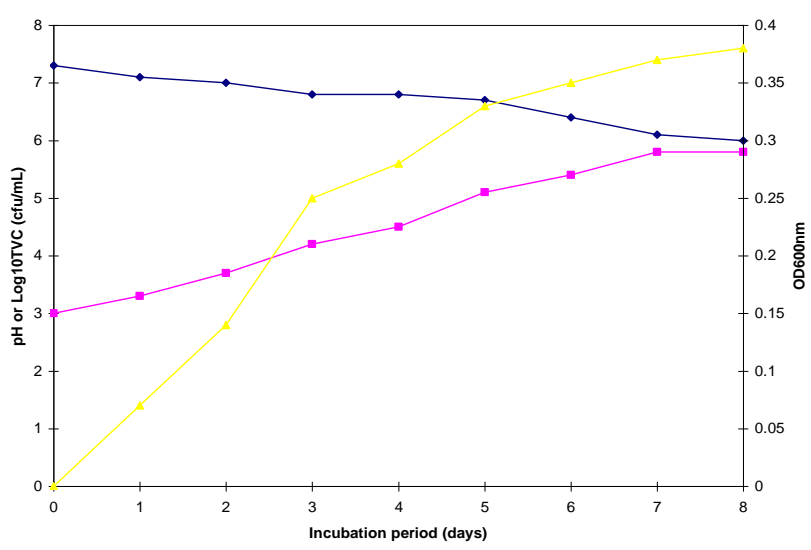

Figure 4. Growth profile of Pseudomonas stutzeri on diesel.

$\rightarrow-\operatorname{LogTVC}(\mathrm{cf} / \mathrm{mL}) \quad \rightarrow-\mathrm{pH}$ of culture medium $\quad \longrightarrow$ OD600nm

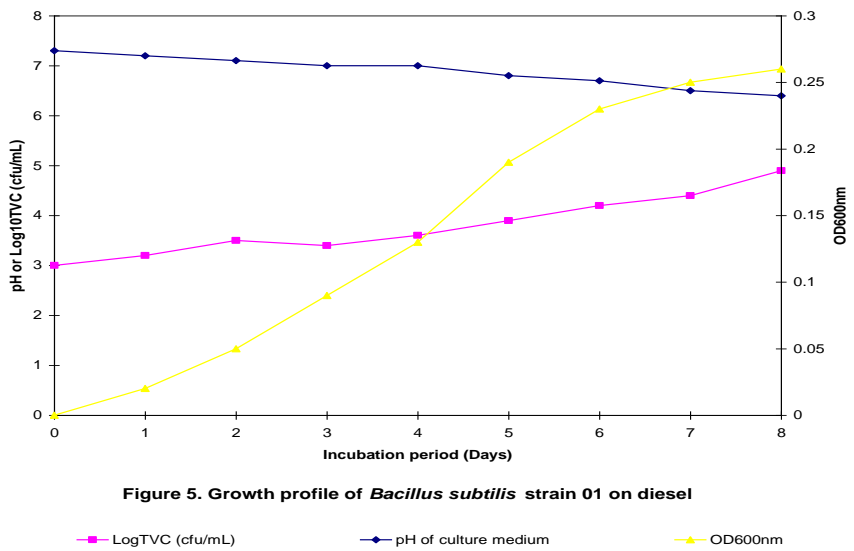

Fig.6 Plasmid profile of hydrocarbon degrading bacterial isolates

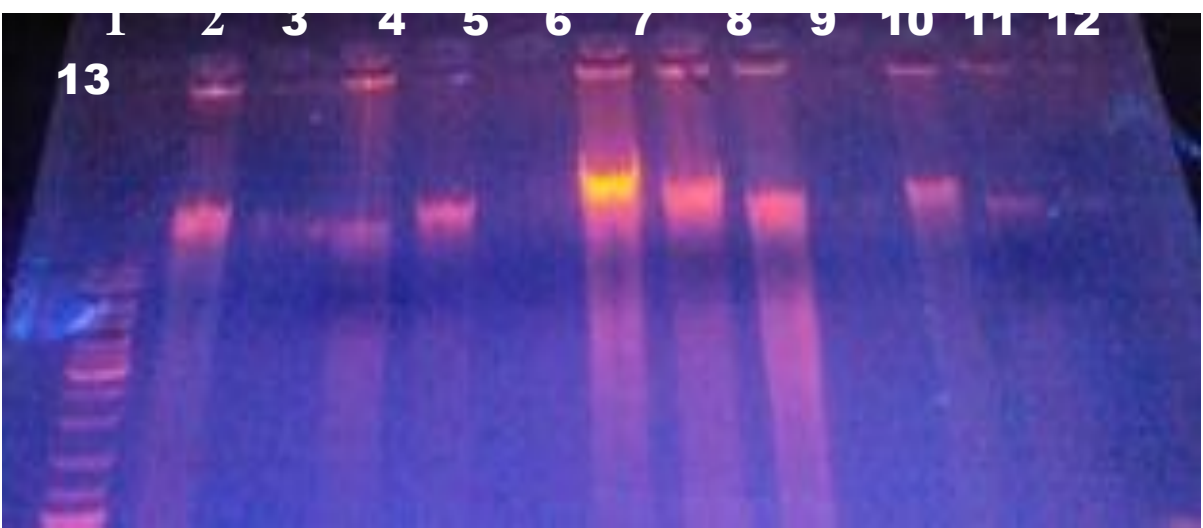

Lane 1 - DNA marker, Lane 2to 9 - Proteus mirabilis, Lane 10 to 11 - Serratia marcescens, Lane 12 to 13 Escherichia coli 
Fig.7 Plasmid profile of bacterial isolates

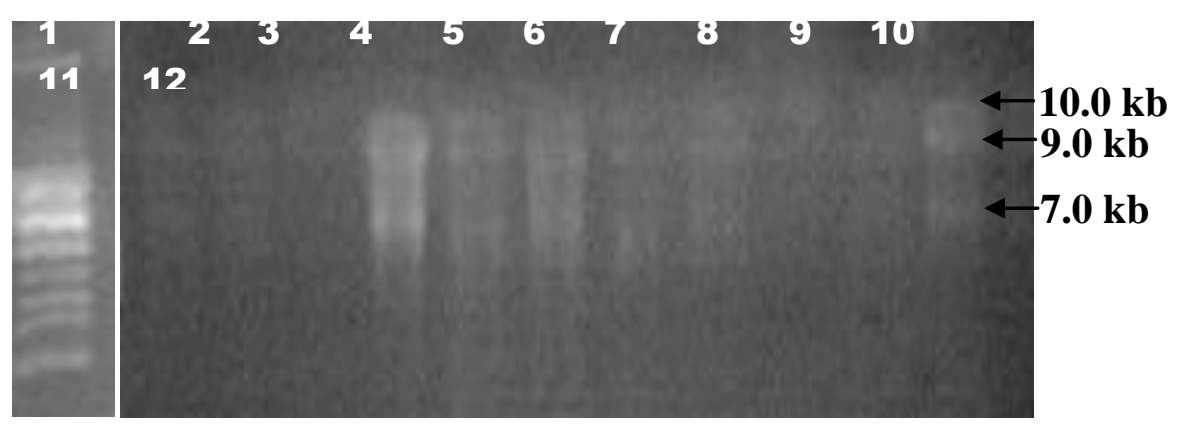

Lane 1 - DNA marker, Lane2 to 8 - Pseudomonas aeruginosa, Lane 9 to 12 - Pseudomonas stutzeri

It was observed that organisms with the highest specific growth rate had the lowest mean generation time (Pseudomonas aeruginosa 04, Pseudomonas stutzeri 06, Proteus mirabilis 02, Serratia marcescens 02 and Bacillus subtilis 01) while the organisms with the lowest specific growth rate had the highest mean generation time (Pseudomonas aeruginosa 07, Pseudomonas stutzeri 02, Proteus mirabils03, Serratia marcescens 01 and Bacillus subtilis 02).

The growth profiles showed that none of the bacterial isolates exhibited lag phases which suggested acclimation time being zero as well as inherent presence of the metabolic system for utilization of petroleum hydrocarbon. This agreed with previous findings (Amund, 1984; Okerentugba and Ezeronye, 2003; Nwaogu et al., 2008).

The randomly selected 24 isolates were screened for the presence of plasmid DNA. The marker used was EcoATCC25922 with $10 \mathrm{~kb}$ pair as standard molecular weight marker. Some of the isolates screened carried multiple plasmids of molecular size varying from $7 \mathrm{~kb}-23.1 \mathrm{~kb}$. Among the isolates, plasmids were not detected in 2 isolates (Proteusmirabilis 05 and Serratia sp. 01).This study revealed that organisms with more number of plasmids were resistant to less number of antibiotics. Contrary to literature, there was no positive correlation between the number of plasmid harbored by an isolate and resistance to various antibiotics tests.

Indigenous bacterial consortium made up of Pseudomonas species, Proteus mirabilis and Bacillus subtilis could be a cheap natural resource for the removal of petroleum hydrocarbons from natural environment.

The integration of this bacterial consortium into the bioremediation process in tropical countries and the world at large would rescue our oil-polluted environment since these organisms are environment - friendly.

Further understanding of the metabolic process through which microorganisms mineralize petroleum hydrocarbons and the application of biotechnological process could generate novel bacterial that would singly metabolize petroleum hydrocarbon from oil impacted environment into carbon (IV) oxide, water and energy.

\section{References}

Abbasian, F., Lockington, R., Mallavarapu, M. and Naidu, R. (2015). A comprehensive review of aliphatic hydrocarbon biodegradation by bacteria. Applied Biochemistry \& 
Biotechnology176 (3): 670-699.

Adebusoye, S.A., Ilori, M.O., Amund, O.O., Teniola, O. D., and Olatope, S.O. (2007). Microbial degradation of petroleum hydrocarbons in a polluted tropical steam. World J. Microbiology \& Biotechnology. 23:1149-1159.

Das, K., and Mukherjee, A. K. (2007). Crude petroleum - oil biodegradation efficiency of Bacillus subtilis and Pseudomonas aeruginosa strains isolated from a petroleum - oil contaminated soil from North - East India. Bioresources Technology. 98: 1339 - 1345.

Gerhardt, P., Murray, R.G E., Costilow, R.N., Nester, E. W., Wood, W. A., Krieg, N. $\mathrm{R}$. and

Phillips, G. B. (1981). Manual of methods for general bacteriology. American Society for Microbiology Washington, DC 20006. Pp. 409 - 425.

Hu, G., Li, J., \& Zeng, G. (2013). Recent development in the treatment of oily sludge from

petroleum industry: a review. Journal of Hazardous Materials261: 470-490.

Kado, C. I., and Liu, S. T. (1981). Rapid procedure for detection and isolation of large and small plasmids. $J$.
Bacteriology145: 1365-1373.

Kasper, C. W., Burgess, J. J., Knight, I. T. and Colwell, R. R. (1990). Antibiotic resistance

indexing of Escherichia coli to identify sources of fecal contamination in water. Canadian J. Microbiology 36: $891-894$.

Nwaogu, L. A. Onyeze, G. O. C., and Nwabueze, R. N. (2008). Degradation of diesel oil in a polluted soil using Bacillus subtilis. African Journal of Biotechnology. 7(12): 1939 - 1943.

Okoh, A. I., and Trejo - Hernandez, M. R. (2006). Remediation of petroleum hydrocarbon polluted systems: exploiting the bioremediation strategies. African J. Biotechnology5: $2520-2525$.

Olukoya, D. K. and Oni, O. (1990). Plasmid profile analysis and antimicrobial susceptibility patterns of Shigella isolates from Nigeria. Epidemiology \&Infections 105:59-64.

Rosenberg, E. (2013). Hydrocarbon-oxidizing bacteria. In: The prokaryotesProkaryotic physiology and biochemistry New York: Springer. Pp. 201-214.

\section{How to cite this article:}

Olusola A. Ojo-Omoniyi and Rebecca O. Abegunrin. 2019. Evaluation of Native Bacterial Consortium from Crude Oil-Impacted Tropical Environment for Integration into Bioremediation Process. Int.J.Curr.Microbiol.App.Sci. 8(06): 1291-1302.

doi: https://doi.org/10.20546/ijcmas.2019.806.156 